\title{
What makes theological education "theological"? A South African story on the integrity of theological education 1
}

P J Robinson \& D J Smit

\section{ABSTRACT}

What makes theological education "theological"? A South African story on the integrity of theological education

David Tracy claims that the contemporary emergence of a sociological imagination is as crucial for theological self-consciousness as the earlier rise of historical consciousness among theologians. The authors are of the opinion that the rapid and fundamental social changes in South African society over the past few years have accelerated this "emergence of a sociological imagination" amongst South African theologians. In three sections, they point to three clusters of questions that have therefore become increasingly important, namely questions related to the growing awareness of the crucial role of social location or context, questions arising from a growing acknowledgement of public responsibility, and questions concerning the integrity of theological education, $i$ e the question on what makes theological education "theological".

\section{ON THE EMERGENCE OF A SOCIOLOGICAL IMAGI- NATION}

"Like the earlier rise of historical consciousness amongst theologians, the contemporary emergence of a scciological imagination is, however initially unnerving, crucial for theological self-consciousness".

Few insights have been more fundamental to the recent work of South African theologians than the truth in these words from the opening paragraphs of David Tracy's well-known book on Christian theology and the culture of pluralism, The analogical imagination ${ }^{2}$. Tracy continues his argument about this "emergence of a sociological imagination" by painting a tentative "social portrait" of a theologian. It is in this context that he draws his well-known distinctions between the three publics that theology, as a social discourse, addresses, namely the public of society, the public of the academy, and the public of the church. 
The use of Tracy's distinctions has become commonplace in South African theology in recent years ${ }^{3}$. To a large extent, it has been forced on us through the rapid and fundamental social changes taking place in South African society over the past few years. These distinctions have helped us to make some sense of the radical challenges we faced as theologians and to bring some order, not in our answers, but in our questions.

Perhaps one could summarise some of the main concerns forced upon us through this sudden "emergence of a sociological imagination" in the form of three clusters of questions, arising a) from an increasing awareness of the crucial influence of our "social location" or, as some prefer to say, our "context", on our theological activity; b) from a growing acknowledgement of our public "responsibility" as theologians; and c) from a renewed interest in the "integrity" of theology, i.e. in the question what makes theological education "theological". In the following three sections we briefly tell the story of this emerging sociological imagination using these three categories.

\section{SOCIOLOGICAL IMAGINATION: AWARENESS OF SOCIAL LOCATION}

It is almost a commonplace, but still necessary to keep in mind: South African theologians have become extremely aware of the important influence of their own social locations, or, as many prefer to say: their contextuality, on the way they do theology.

A variety of slogans witness to this growing awareness: Already during the sixties, but increasingly during the seventies, many ministers, religious leaders, theological students, teachers and scholars called for more relevant theology ${ }^{4}$. They experienced the theology taught in the seminaries and the faculties as irrelevant, useless, alien. They often revolted against Western theology, against curricula, against text-books, against institutions.

In the early seventies black theology became a battle-cry amongst many students and ministers, particularly in the circles of black consciousness ${ }^{6}$. Towards the end of the seventies the expression contextual theology became more popular ${ }^{7}$. In the early eighties the notion of prophetic theology was winning the day amongst those who wanted to see more relevant theology being done in South Africa ${ }^{8}$. During the latter part of the eighties the Kairos-document became so widely known in South Africa that kairos theology became the slogan everyone understood?. Opponents and critics of these movements, often inspired by overseas 
fundamentalist interests, regularly used the expression liberation theology to lump these typically South African initiatives together with international theological trends ${ }^{10}$. At the moment, calls for Africanisation are becoming more and more popular ${ }^{11}$.

All these stories have often been told and it is unnecessary to repeat them here ${ }^{12}$. The overall impact, however, on South African theology cannot be ignored. These were no innocent, harmless, scholarly debates. All these initiatives were imbedded in the struggle against apartheid. The awareness of the "contextual" nature of all theology was not merely a neutral, descriptive and scholarly insight. It was an ideological tool, intended to unmask the fact that insights, ideas, and language were used as weapons in a social struggle. In fact, it was precisely because everybody started using the notion of "context", as a harmless description of that which is always the case, thereby giving legitimacy to "Western" theology and sometimes even to apartheid theology, as just another form of contextual theology, that those in the struggle rejected the term in favour of prophetic or kairos theology. In short, the "emergence of a sociological imagination" in South African theology was to a very large extent an integral part of the struggle against apartheid.

It was therefore only to be expected that the radical political, social and economic transformations, leading to a so-called "new South Africa", would again have a major impact on South African theology. We are no longer within an apartheid society. The social location of theology has changed and it is still changing - and South African theologians are very much aware of that.

What has happened in South Africa and what is happening? How should one describe the changing social location for doing theology in South Africa? That is a difficult and in itself controversial question. The diverse answers, however, will determine how one will perceive the new realities South African theology has to take into account, the new challenges South African theologians have to face, the new issues we have to address... the new slogans that will become popular.

One obvious way of describing the present process is in political terms: South Africa is becoming a democracy and a civil society. Obviously this - radically new - social location will have major implications for doing theology:

South African churches and theologians will have to learn how to live in a democratic society ${ }^{13}$; how to behave themselves in a society where freedom of religion is guaranteed by the constitution ${ }^{14}$. Already a serious public conflict is raging about the so-called "secular state"15. Questions are 
asked about the relationship between church and state in the constitution, and about the teaching of religion in schools ${ }^{16}$. The position of Christian, sometimes even denomination, seminaries and theological faculties within state-funded universities is at stake ${ }^{17}$. The status and the nature of departments of religion at universities are being debated anew ${ }^{18}$. Other religions come to the fore with claims to teach their own traditions within state-funded universities ${ }^{19}$. A South African Academy for the Study of Religion has been established, incorporating many of the traditionally Christian scholarly societies ${ }^{20}$. Religions, including the so-called traditional African religions, are cooperating regarding many public issues, including religious broadcasts in the public media ${ }^{21}$.

Christian theology must find its role in a civil society22: More and more discussions are held about issues of public religion, the public church, and a public theology 23 . Questions are raised about the task of the church and of theology in nation-building ${ }^{24}$, in dealing with the legacy of apartheid, reconciliation and healing the nation ${ }^{25}$, in learning to face and live with "the other", in creating a common moral language and a moral fabric ${ }^{26}$.

A second possibility to describe the changing context in South Africa is to use economic categories: South Africa urgently needs development, reconstruction and growth. In fact, the government's RDP - the "Reconstruction and Development Programme" - has already been widely accepted as the new overall ideological framework or vision for the nation 27.

The university-system, in fact, the total educational system ${ }^{28}$, research $^{29}$, but also religions, churches and theology, are all deeply effected by the RDP. This again has serious implications for the institutional policies and planning of theological training institutions. Two presently popular key-words recall some of them: prioritization and rationalization. "Setting new priorities" in the light of the ideals of the RDP has a positive ring to it. "Being rationalized" in the light of the realities of the RDP has a negative ring to it. Both will obviously impact severely on the social settings of doing theology in South Africa ${ }^{30}$.

A third way to understand the changing South African reality is to use geographical, demographical or cultural concepts: We must locate ourselves in Africa ${ }^{31}$, or in the Third World, where realities of urbanization, industrialization, development, inculturation, poverty, and ethnic strife all take on special meaning and all pose special challenges and priorities to theology. We must do cultural analysis. We must do local theology32. 
The point is simple: As was the case during the years of struggle, the changing South African context will again have a major impact on the way we do theology and on our institutional planning.

\section{SOCIOLOGICAL IMAGINATION: ACKNOWLEDGEMENT OF RESPONSIBILITY}

A second extremely important aspect of this emergence of a sociological imagination in South African theological circles, is the fact that people increasingly became aware of the moral dimension of this process. South African theologians have increasingly asked questions about responsibility.

Asking questions about responsibility and ethics have become commonplace in a number of theological disciplines in South Africa: Biblical scholars talk about the ethics of interpretation ${ }^{33}$, the ethics of reading, and the ethics of writing, often linked to questions about the future of these disciplines in South Africa. Systematic theologians and ethicists ask questions about their responsibilities in society and in the church, about "the ethics of ethics". Missiologists reflect about their responsibility in a radically changed situation. Practical theologians and ministers of religion organise conference upon conference and meeting upon meeting to talk about the responsibility of the church in the new South Africa. And obviously historians continue debating about the morality of historical reconstruction in the country.

Once again, the experiences of the struggle against apartheid play a major role in this self-awareness. We know only too well that scholarship, that research, that a whole educational system, that theological training, that the church, that religion, can become part of an ideological and oppressive system. We know that we can no longer take our own work for granted, but that we must ask questions of responsibility, of vocation, of ethics.

Perhaps this is why rhetorical theory has become so popular in South African scholarship, including theological circles. It provides the tools to understand that human discourse, including theology, should not only be evaluated in terms of the logos, the argument, but also in terms of the ethos and the pathos. Questions concerning who says what to whom and why, in whose interest, are also important. In fact, Elisabeth Schüssler Fiorenza's address on the ethics of interpretation and her plea for a rhetorical-critical de-centering of theological education contributed much to the emergence of this aspect of the sociological imagination in South African theology. And matters of race and sex are present and alive in 
almost every theological discussion in South Africa ${ }^{34}$.

\section{SOCIOLOGICAL IMAGINATION... AND THE INTEGRITY OF THEOLOGY?}

However, it is clear that more must be said. The sociological imagination alone cannot answer the question what theology is or what theologians should be doing. Theology must have its own identity, its own integrity. But: what is theology? And: what is the responsibility of theological education? What is "the basic aim and purpose" of theological study? What is the vocation of a theologian? What is theological competence?

South African theologians have discussed these questions over the past few years almost without cease. But we found it very difficult to agree on an answer. Having asked some of the best-known theologians in the world about the vocation of a theologian, Theodore Jennings' conclusions pointed in a similar direction. They all seem to agree that what they are doing is of the utmost importance, but they do not share the slightest agreement on what that is ${ }^{35}$. We often agreed that Charles Wood was correct when he said:

"It is by no means universally granted that 'theological education' really means theological education - that it centers in the teaching and learning of theology. It can be and often is regarded simply as the collective term for the assortment of disparate things which make up a curriculum in what is conventionally called a theological school; or it can be taken as a synonym for 'education for ministry' - and again the adjective 'theological' implies nothing about the nature of the educational process, except perhaps that something called 'theology' was once a prominent part of it" ${ }^{36}$.

In our attempts to learn from others, we have, over the past years, tried to listen to the conversations ${ }^{37}$ about these questions elsewhere in Africa ${ }^{38}$, in Germany ${ }^{39}$, in the Netherlands and in the United States of America ${ }^{40}$.

Eventually, most of us have come to agree that we face three basic options in theological education in South Africa today. The contrast between Athens and Berlin, often used by David Kelsey to situate major positions in the USA into a typology, has proved helpful41. He asks about the "aim and purpose" of theology, about "the nature of a theological school", and says "that the purpose of a theological school is to seek to understand God more truly, and that a school's 'nature' follows from this 'purpose'" 42. This can, however, be constructed in diverse ways. Kelsey then uses his typology to describe different options for theological schools. 
The first option for us, in South Africa, would be to follow an Athens-option and to concentrate on "formation", on paideia, on education, spirituality, wisdom, character. The second option would be to follow Berlin and to concentrate on "professional training", on the kind of ministers the congregations and the churches need, and to train them, to equip them as practically as possible. The third option, a variant of Berlin, would be to concentrate on "science", on scholarship and research, to accept the independence and even conflicts between the traditional theological disciplines and not to inquire after any kind of "unity" in the theological enterprise.

Different institutions in South Africa have made different choices in this regard ${ }^{43}$. However, in the light of the socio-economic, the political, and the cultural realities referred to earlier, it has become increasingly difficult for theological institutions in South Africa to close our eyes to this challenge and to continue with the third option, as if it makes perfect sense for us to continue with "scientific theology", "scholarship" and "research", while ignoring fundamental questions concerning the theological nature, the integrity, of the entire enterprise.

Perhaps the most crucial impact of the emergence of a sociological imagination forced upon us has been this insight that we now realize that it is impossible to discuss these options and to make these choices concerning the nature of theological education in a vacuum. The real-life context, the socio-historical conditions, co-determine what is possible and what is necessary.

In their valuable final report for the Lilly Foundation on Lilly endowment grants for theological education research, Barbara Wheeler and David Kelsey make this point clearly and convincingly. They plead for, what they call, "integrity" in research on theological education. They argue that the two processes of "institutional planning" and "reflection on basic aims and purposes" should be integrated into one, comprehensive undertaking, in order to make it more rational and responsible ${ }^{44}$. We fully agree. Awareness of social location and acknowledgement of responsibility go hand in hand with reflection on the aim and purpose of the theological enterprise.

\section{NOTES:}

1 Hierdie voordrag is deur P J Robinson gelewer tydens die Internationale Seminar für interdisziplinäre Theologie van die Switserse Teologiese Vereniging se konferensie, van 14-17 September 1995 te Emmetten, Switserland, oor die tema "Teologie en Sosiologie". 
2 D Tracy, The analogical imagination. Christian theology and the culture of pluralism, London 1981. The words are from page 4, in the Introduction to Chapter 1 . In his recent analysis of modernity and post-modernity as ambiguous traditions, he again argues: "All who demand the bracing honesty of an historical consciousness can now also note the further ethical concern with the realities of social location (gender, race, class)", in "Theology and the many faces of post-modernity", Theology Today 51/1 (1994), 105. See also D Tracy, On naming the present, London 1994.

3 Several well-known South African theologians have used these distinctions, including D J Bosch, B A Müller, J Cochrane, H W Rossouw, J W de Gruchy, and B C Lategan. See e g D J Bosch, "The nature of theological education", JTSA 77 (1991), 3-17. A major national conference of the South African Theological Society used this division in 1992 in order to discuss the public responsibility of theology in South Africa. See also the earlier volume of essays G Loots (ed), Listening to South African voices, UPE 1992.

4 Ministers who furthered their theological studies overseas were particularly emphatic about this need for "relevancy" when they returned to South Africa. See e $\mathrm{g}$ the thesis in the doctoral dissertation by UWC-church historian, J C Adonis, Die afgebreekte skeidsmure weer opgebou, Amsterdam 1982; or the reflections by C J Loff, a UWC church historian, in: "Relevante teologiese opleiding", Apologia 2/1 (1987), 11-16.

5 This became very clear in research done by a former UWC-colleague in Practical Theology, G Bam, "Vrae rondom die opleiding van leraars vir die NG Sendingkerk met die oog op effektiewe gemeentelike bediening aan die armes", in: P J Robinson (ed), Die kerk en die arme - enkele teologiese perspektiewe, Bellville 1984, 81-95.

6 In the early seventies a first volume of essays on black theology was published, see M Motlabi, Essays on Black Theology, Johannesburg 1972. On several major conferences during these years serious reflection was done about the task and the future challenges for black theology. See e $\mathrm{g}$ The unquestionable right to be free. Essays in black theology, I J Mosala \& B Thlagale (eds), Johannesburg 1986. For an even later discussion, see e g B Goba, An agenda for black theology, Johannesburg 1987.

7 It was particularly popularised by the well-known Institute for Contextual Theology, with theologians like Frank Chikane, Albert Nolan, Smangaliso Mkatshwa, and others. See e $\mathrm{g}$ the document What is contextual theology? Braamfontein 1985.

8 B Thlagale \& I Mosala (eds), Hammering swords into ploughshares, Johannesburg 1986, this preference for a "prophetic" approach is, for example, already clear. 
9 Both the The Kairos Document. Challenge to the Church. A theological comment on the political crisis in South Africa, Braamfontein 1986, and the Road to Damascus. Kairos and conversion, Braamfontein 1989, demonstrate this approach.

10 "Liberation"-theology became a very controversial term in South Africa, particularly because the guardians of the status quo used the expression to associate all ecclesial and religious criticism of apartheid as communist, Marxist, part of the "total onslaught" against "western civilization and Christianity". The chaplain corps played a major role in this propaganda, as well as the public media.

11 This appeal has of course been made for a long time, in Africa and specifically in South Africa. See e g B Goba, "The task of Black theological education in South Africa", JTSA 21 (1978), 19-30, and M S Mogoba, "Theological education in Africa", Missionalia 8/1 (1980), 27-31. During several recent conferences on the present task of theology in South Africa, this sentiment has been well represented. These ideas are obviously important all over Africa. See e $g$ the recent All Africa Consultation on the viability of ministerial formation today, held at Kuruman from 2-5 August; 1995, under the initiative of Dr John $\mathrm{S}$ Pobee from the WCC. For earlier attempts, see e $\mathrm{g}$ the volume of contributions, J S Pobee \& J N Kudadjie (eds), Theological education in Africa: Quo vadimus?, Accra 1990.

12 See e $\mathrm{g}$ the scholarly discussions in J N J Kritzinger, Black theology - challenge to mission, doctoral thesis, UNISA 1986, or F B O Nel, Die storie om mens te wees... Die storie van swart teologie in Suid-Afrika, MTh-thesis, UWC, Bellville 1989.

13 J W de Gruchy has recently published a major study on Christianity and democracy from a South African perspective, Christianity and democracy. A theology for a just world order, Cape Town 1995.

14 There are still serious debates in South African church, theological, and religious circles about the precise implications of "religious freedom" and about the way it should be formulated and interpreted in the new constitution, at present in a process of being written.

15 Inspired from the circles of right-wing evangelical groups, but popularised because it caught the imaginations and inspired fear in many Christians, there has recently been widespread protest in the country, demonstrated in a march on Parliament, to reject the so-called "secular state", that is supposedly being established by the new government in the new constitution.

16 The discussions to decide the future of religion in public schools in the country are still far from decided. A wide range of proposals are at present being considered in educational and religious circles. 
17 The story of the presence of seminaries and theological or divinity faculties or departments in the universities is a very confusing, but an extremely important one. See e $\mathrm{g}$ the 450-page volume with essays of the Hervormde Teologiese Studies, Jaargang 50/1 \& 2 (Junie 1994). For an overview of the history of theological education in a particular church tradition, P J Robinson, "Teologiese opleiding in die Verenigende Kerke”, Apologia 5/2 (Augustus 1990), 39-60; and for a discussion of the tension between theological training and university ethos, R J Stevens, "Theological education and the ethos of the University of the Western Cape", Apologia 2/1, (1987), 29-33. At present, the state of affairs which was inherited from the past is being challenged from all sides and in a number of ways.

18 The story of the establishment of "Biblical Studies" as a subject in South African schools and therefore at South African universities is even more remarkable. See for the present state of affairs e g H P Müller, "Tertiary academia of religion in South Africa - some statistical perspectives", Scriptura 53 (1995), 125-140.

19 Interesting proposals in this regard have been given to the CUP, the South African Committee of university principals. These draft proposals read as follows: "(1) Academic and non-sectional courses in theological studies belong in universities. Religion and religious aspiration is so general a human phenomenon that reflection on human beings' efforts to come to terms with it and find meaning in life must be an important intellectual discipline. In as markedly a religious country as South Africa, failure to provide for the study of religion in its own right in universities would amount to ignoring a major element of South African reality. (2) In its theological studies programmes, the S A university system should in principle be open to giving attention to the range of religions, although particular religious traditions may be emphasised to meet regional interests. The main intention here is that someone from a particular religious tradition or with a particular interest in that tradition should be able to pursue the study of it in ways hospitable to the ethos of that tradition. (3) Theological courses, like all other courses offered by a university should be presented by lecturers appointed by the university and be open, in the sense of being available in principle to all students registered for the diplomas and degrees. The theme for the 1995-conference, from 24-26 September, was Civil society, democracy \& development. (4) Specific religious groups may negotiate to offer with particular universities confessionally-related vocational and academic courses on campus in association with the theological studies programme. Universities will retain final control over the standards of academic courses which are credited towards degrees or diplomas. The costs of all such programmes, e $\mathrm{g}$ employing lecturers and use of facilities must be negotiated by the parties concerned. (5) Rational use of resources requires a) that curricula be designed to meet the needs of as wide a group of clients as practically possible, and b) that the qualification structure allows as many useful exit points as possible. Identifying client groups is thus very important. The obvious groups 
such as teachers, religious workers and ministers of religion, may be augmented for specific purposes by doctors, dentists, lawyers and social workers, and for general interest by liberal arts students. (6) Reducing the cost, enhancing the quality, and increasing the accessibility of postgraduate programmes must be a priority. In planning postgraduate programmes, the possibilities of distance education and inter-institutional cooperation must be borne in mind. Making it possible for students to spend relatively brief periods on campus, and perhaps to draw on the facilities of several institutions, is an attractive option. (7) It is desirable that each university should have distinctive focuses for its postgraduate research. (8) Theological studies programmes will be responsive to the demand for shorter, non-qualifying courses for specific communities or for the general public, as far as this is practical”.

For one example, namely the present state of Muslim studies at South African universities, see A I Tayob, "Islamic Studies in South Africa", Scriptura 53/2 (1995), 65-72.

20 At the beginning of 1994, a new scholarly society with wideranging membership has been established, namely the $S A A R$, the South African Academy of Religion, with S Maimela, a well-known black theologian from UNISA, as first president. The essays of the first conference are currently being published by Unisa, Pretoria, and will be titled Religion in reconstruction, edited by J W de Gruchy \& S Martin. The theme for the next conference, planned for 1996, is Religious experience in Africa.

21 The public broadcaster in South Africa, the SABC, has recently announced major changes in its religious policies, with far-reaching effect for religious programming in the country. For research into the content and role of these broadcasts in apartheid-South Africa, see e g B A Müller \& D J Smit, "Godsdiens in die openbaar. Tendense in die Afrikaanse godsdiensprogramme van die SAUK", NGTT 32 (1991), 652-665; B A Müller \& D J Smit, "South African radio and television as contexts for exegesis: A case-study of interpretive practices in South African public worship", Scriptura 9 (1992), S9 73-86; and B A Müller \& D J Smit, "Public worship - a tale of two stories", in: J Mouton \& B C Lategan (eds), The relevance of theology for the 1990's, Pretoria, 385-408.

22 Several major conferences on the church, theology, and civil society have been held over the past few years, e $g$ organised by the $S A A R$ and by EFSA, the Ecumenical Foundation of Southern Africa. See e $g$ R Koegelenberg (ed), Church and development: An interdisciplinary approach, Bellville 1992 and $\mathrm{R}$ Koegelenberg (ed), Theology and transformation. A challenge to the church, Bellville 1994. The theme of the 1995-conference, from September 24-26, was Civil society, democracy \& development.

23 The stream of theological reflection on these issues seems never-ending in South Africa. Members, congregations, organisations, students, ministers, faculties, 
denominations, are all continuously talking about public role and public responsibility.

24 A theologian like $\mathrm{C}$ Villa-Vicencio has been deeply involved in issues related to nation-building. See e g C Villa-Vicencio, $A$ theology of reconstruction: Nationbuilding and human rights, Cape Town 1992, and "The quest for a national identity", JTSA 86 (1994), 26-38 (as well as the other essays in this volume on "Democracy, Christians and the election"). Recently, Villa-Vicencio, with C Niehaus, a parliamentarian, edited a Festschrift for Beyers Naudé with important essays on nation-building, Many cultures, one nation, Cape Town 1995. See also the essay by R Petersen from the UWC department of Christian Studies, "Towards a South African theology of non-racism", JTSA 77 (1991), 18-26.

25 Many Christians, theologians, church-leaders and church-groups are involved in discussions about a Truth and Reconciliation-Commission for South Africa. See e g D J Smit, "The truth and reconciliation commission - Tentative religious and theological perspectives", JTSA 90/1 (1995), 3-16.

26 Questions concerning the necessity and the creation of a common (moral) language, concerning difference and unity, concerning multi-culturalism and identity, concerning ways of living with the other, e $g$ through dialogue, are very much on the foreground in theological circles. Several colleagues from the UWC have contributed in this regard. See e $g$ the work of $H$ R Botman, like "Dealing with diversity", in: D Buchanan \& J Hendriks (Eds), Meeting the future, Randburg 1995, 164-172, or his "Managing endings and transforming continuities", in: Niehaus \& Villa-Vicencio (Eds), Many cultures, one nation, 1995; or E Conradie's work on dialogue, “Tracy's notion of dialogue: our last best hope?", forthcoming Scriptura; or D J Smit, "Etiek na Babel? Vrae rondom moraliteit en die openbare gesprek in Suid-Afrika vandag", NGTT 34/1 (1994), 82-92; "Etiese spraakverwarring in Suid-Afrika vandag", NGTT 36/1 (1995), 87-98; "Het Suid-Afrika 'n gemeenskaplike morele taal nodig?", HTS $51 / 1$ (1995), 65-84, and "Oor die skepping van 'n grammatika van saamleef", HTS 51/1, 85-107.

27 The Reconstruction and Development Programme, originally a vision of the ANC, became the overall ideological strategy of the new Government of National Unity. A white paper was accepted, and the different provinces also adopted the Programme. Many churches are discussing their own role within this initiative. See e $g$ Cheryl Carolus, who heads the ANC's department responsible for the $R D P$, "Transformation in South Africa. The role of civil society and the church in the Reconstruction and Development Programme", Bellville, October 1994.

28 The Minister of Education has already indicated that the $R D P$ will in future also determine the priorities of all levels of education, including the universities. In practice, this means that universities, and faculties and departments within 
universities, are already reconsidering their own nature, composition, and activities, including teaching and research, with a view to meet the priorities of the $R D P$.

29 The $H S R C$, the (only) national body encouraging and funding research in the human sciences, has recently published its own list of research priorities for the country, with the suggestion that research in these fields has a better chance of being funded.

30 The recent stories of the few theological and religious departments and faculties in our own region, the Western Cape, already illustrate the enormous effects of these changes very clearly. The developments at the UWC have been almost dramatic over a short period of time. A denominational seminary changed into a denominational, although "open" theological faculty, then into an interdenominational faculty, and then into an ecumenical faculty. Since 1995, it is a Faculty of Religion and Theology, with Christian, Muslim and Hindu scholars on the staff. Other institutions find themselves in similar processes of radical transformation.

31 The well-known African and Tanzanian leader, Julius Nyerere, recently addressed a meeting of theologians and scholars in South Africa, organised by $E F S A$, and made this point very strongly. See J Nyerere, "Africa's development in a global perspective. The sharing of resources in Africa - a challenge to South Africa”, EFSA, Bellville, December 1995.

32 One of the exciting challenges for theological education in South Africa therefore comes from the African Independent Churches. See e $g$ the discussion of theological training in I Daneel, Fambidzano Ecumenical movement of Zimbabwian Independent Churches, Nambo, Gwero 1989, 227-414; and the work by D C van Zyl, a member of the UWC faculty, e $\mathrm{g}$ "The Old Testament in training programmes for the African Independent Churches", Old Testament Essays, 7/4 (1994), 52-61. Senior students in our faculty are extremely interested in issues related to "gospel and cuiture". Many of them are involved in research on the localization of gospel, church, and theology.

33 Many South African scholars have been engaged in these discussions over the past few years, including B C Lategan, Dean of the Arts Faculty of the University of Stellenbosch, in several contributions on hermeneutics, J Botha, whose doctoral thesis on the ethics of reading has just been published by Scholars Press, in the USA, and A E J Mouton, who recently completed her doctoral research, Reading a New Testament document ethically: Toward an accountable use of Scripture in Christian ethics, through analysing the transformative potential of the Ephesians epistle, DTh-thesis, UWC, Bellville.

34 South African scholars have organised an international conference on Rhetoric and Religion in Pretoria earlier in 1995, where Elisabeth Fiorenza was one of the major speakers. Her earlier work on the ethics of interpretation, rhetorical- 
criticism, and the need to de-center biblical studies and theological education has been very influential in stimulating debate in South Africa. The proceedings of the conference will be published during 1995 by Sheffield Press.

35 See T W Jennings, Jr (ed), The vocation of a theologian, Philadelphia 1985.

36 C M Wood, Vision and discernment. An orientation in theological study, Atlanta, Georgia 1985. This is indeed a most helpful study, just like his earlier book The formation of Christian understanding. An essay in theological hermeneutics, Philadelphia 1981.

37 See e g D J Smit, "What makes theological education theological? Overhearing two conversations", Scriptura S11 (1993), 147-166.

38 See e $\mathrm{g}$ the influential article by $\mathrm{J}$ Pobee, "Comments on the future of theological education in Africa", Scriptura 28 (1995), 1-23. In general, Pobee, and the World Council of Churches as such, have had a major influence on theology in South Africa. Recently, some important conferences were held discussing the future of theological training in Africa. Organisations within South Africa, like ASATI, are trying to strengthen their ties with the representatives of theological training institutions in other African countries.

39 To mention only a few names: H E Tödt, W Pannenberg, T Rendtorff, D Ritschl and W Huber, and particularly E Herms.

40 Again, to mention only a few names: Wheeler, Kelsey and Wood themselves, $R$ Lynn, J C Hough, J B Cobb, J Gustafson, D Browning, D R Griffin, G D Kaufman, C Long, J N Poling, M Stackhouse, C Dykstra, R Chopp, F S Fiorenza, P Knitter, P Paris, T Ogletree, M Taylor, H Frei, S Ogden and in particular E Farley.

41 We refer particularly to his two books Between Athens and Berlin. The theological education debate, Grand Rapids, MI 1993, and To understand God truly. What's theological about a theological school, Louisville, KY 1992.

42 To understand God truly, 15. He argues that it is misleading to talk about "theological education" in abstraction from the particular socio-economic context of particular schools. The "sociological, political, and economic dimensions of the enterprise (must be) at the center of the discussion". We fully agree with that. He adds that three characteristic features of schools must be distinguished and kept in mind in any attempt to describe them: the subject matter that focuses its common endeavour; the understanding it seeks through study of that subject matter; and the kind of community the school is. Again, we found that useful.

43 In our own faculty at the University of the Western Cape we opted for an approach where the training of ministers for the traditional ministry is no longer 
the only or, in fact, primary focus. We concentrate on the formation of Christian character and the formation of religious leadership in general. In this process, the departments and the disciplines in the faculty underwent major institutional changes. In our region, however, other institutions are still making other options.

44 It is worthwhile listening to what they have to say: "At many points in this report, we have criticized the division of the research program into two parts... We now think that this division was a serious mistake. It creates the impression that while leaders and planners in theological education need certain kinds of useful information, that information can be useful to them even if it is unshaped by reflection on the nature and purpose of theological education. Conversely, it suggests that theological reflection on theological education is valid even if it is uninformed by (research) about institutional realities, power structures, values and patterns of activity. Neither, in our view, is the case. The integrity of theological education in fact demands that institutional practices be shaped by theological convictions about purpose and that purposes be hammered out in light of the institutional realities and context of actual schools. Therefore we urge that special support be given in the future to research that brings accurate facts about theological education into fruitful interplay with theological ideas about it, and also to creating conversations about research that contend with both ideas and information. We are convinced that theological educators cannot frame the future of their institutions with integrity unless they become practiced in facing questions of purpose and questions of policy as integral to each other". B G Wheeler \& D H Kelsey, Lilly Endowment Grants for Theological education research, Auburn Theological Seminary, New York City 1990, 46. 